DOI: $10.2478 / \mathrm{v} 10025-007-0010-\mathrm{x}$

JOURNAL OF WATER

AND LAND DEVELOPMENT

J. Water Land Dev. No. 10, 2006: 121-131

\title{
Water erosion in the catchment basin of the Jeleni Brook
}

\author{
Adam KOĆMIT, Marek PODLASIŃSKI, Matgorzata ROY, \\ Tomasz TOMASZEWICZ, Justyna CHUDECKA
}

Department of Soil Erosion and Soil Reclamation, University of Agriculture in Szczecin, Papieża Pawła VI nr 3, 71-442 Szczecin, e-mail: erozja@agro.ar.szczecin.pl

\begin{abstract}
The study on water erosion in the catchment basin of the Jeleni Brook was carried out in the years 1995-1999. The catchment of the Jeleni Brook has complex relief, receives frequent precipitations and thus is more threatened by water erosion. Soil cultivation and water from quickly melting snow can also be the factors affecting soil erosion. Waters from the melting snow produce rills of the following dimensions (mean values): width from 11.5 to $13.6 \mathrm{~cm}$, depth - from 6.4 to 7.1 $\mathrm{cm}$ and length - from 39 to $112 \mathrm{~m}$. The mean values of soil losses vary from 0.5 to $2.02 \mathrm{t} \cdot \mathrm{ha}^{-1}$.

Erosion caused by intensive storm precipitation occurs less frequently but makes much higher soil losses. One of the registered incidents shows that $51.6 \mathrm{t} \cdot \mathrm{ha}^{-1}$ ( $4.5 \mathrm{~mm}$ of soil layer) can be washed out from the area of $0.66 \mathrm{ha}$. Combined effect of outwashing and ploughing in lower parts of slopes created new forms of relief such as agricultural terraces (escarps). Agricultural terraces assume the shape of scarps up to $2 \mathrm{~m}$ high and of different length (e.g. $150 \mathrm{~m}$ ) along with the land use borderlines between e.g. forest and field or field and grassland.

Agriculturally used soils within this catchment need protection based mainly on agrotechnical measures or on alteration of land use. Some areas should be afforested.
\end{abstract}

Key words: erosion factors, irrigation, erosion sediments, soil losses, tillage erosion, water erosion

\section{INTRODUCTION}

Catchment of the Jeleni Brook is the place where water erosion occurs more often than in other areas in West Pomerania (Fig. 1). Moreover, water erosion is associated with the higher rate of soil losses. That is why the study on water erosion in this catchment was conducted in the years 1995-1999. Detailed analyses were concentrated on representative area of the studied catchment in Brwice village, but observation and registration of water erosion were carried out over the whole area of the catchment and its borders. Erosion rills were registered by measuring their width, depth and length at characteristic places. Before measurements the erosion deposits accumulated in deluvial fans were covered by a grid of perpendicular lines at fixed intervals and then the fan range in space was projected 


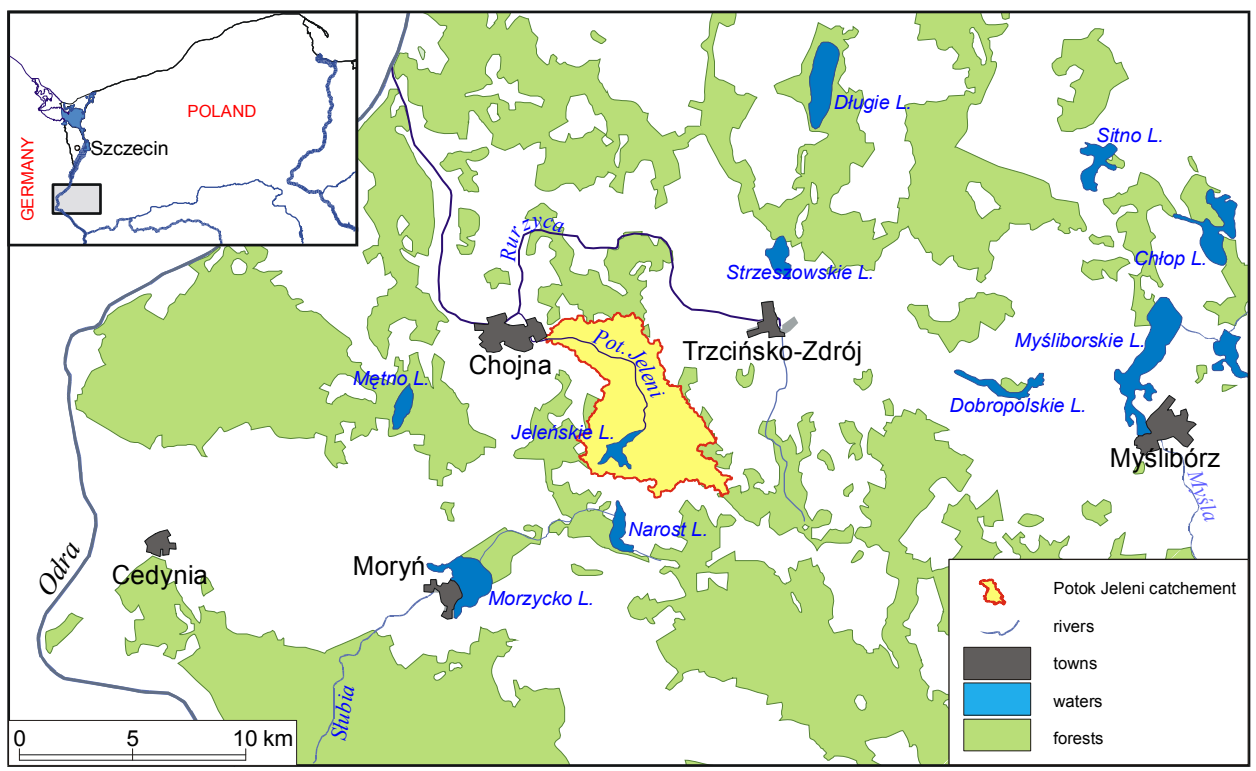

Fig. 1. Location of the catchment basin of the Jeleni Brook

and deposit thickness at intersection points was determined. Deposits (sandy material, silt and clay) from selected sites were taken for bulk density determination.

The morphology and properties of eroded soils were studied on eroded slopes, Soils and deluvial sediments were analysed at zones of aggradation down to the parent material.

To describe present status of arable lands transformed by erosion, forest not eroded soils (with undisturbed diagnostic horizons) were studied as reference material.

The aim of the study was to determine water erosion rate, to characterise deluvial deposits and changes in relief caused by ploughing (agricultural erosion).

\section{MAIN FEATURES OF THE JELENI BROOK}

The catchment basin of the Jeleni Brook is a small agricultural-forest catchment (PODLASIŃSKI, 2001a,b). It encompasses frontal moraines built of boulder loams and sands. Terrain depressions are covered by peat soils. Relief is undulated, in some places - hilly (Fig. 2). Sixty percent of the catchment is covered by forests; the remaining part is used by agriculture, mainly as arable lands.

Catchment area is occupied by small private farms located in villages Brwice, Czartoryja, and Jelenin. Only some areas were once owned by State Farms. Farms 


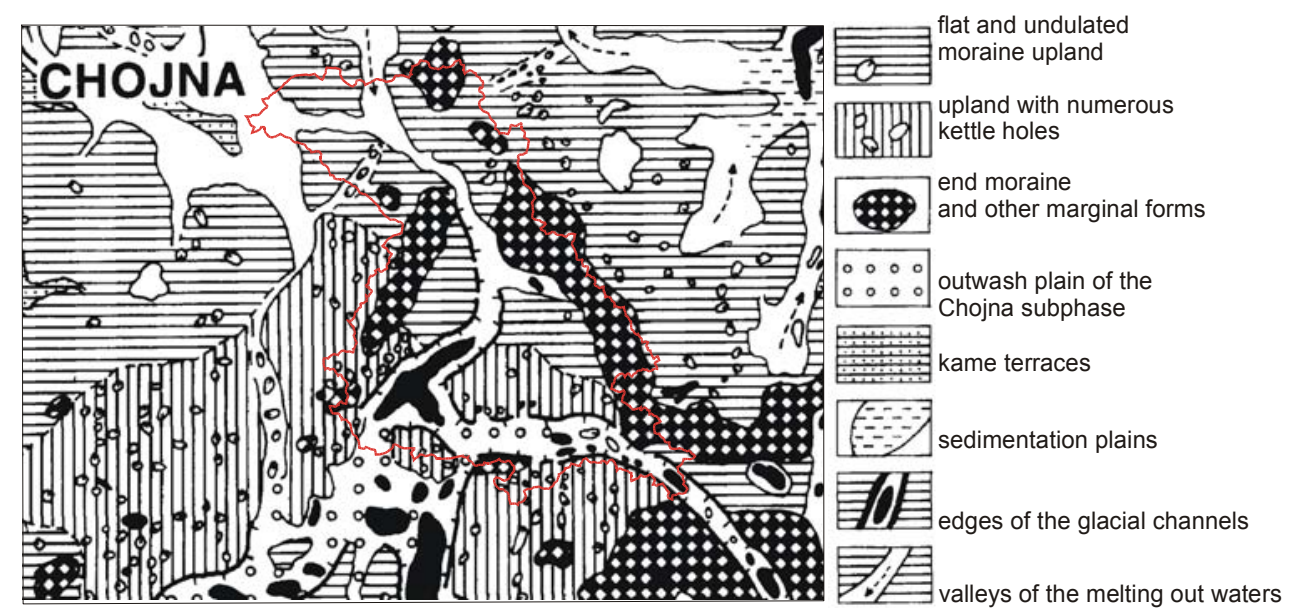

Fig. 2. Fragment of geo-morphological map of the catchment basin of the Jeleni Brook (after KARCZEWSKI, 1968)

are bordered along a specific net of lines in a form of furrows or boundary stripes, which very often overlap on steep areas (tab. 1). Intensive precipitations are also specific for this catchment. According to KoźMIŃSKI and TRZECIAK (1978), the mean number of days with precipitation above $30 \mathrm{~mm}$ did not exceed 6 every 10 years, and precipitation exceeding $50 \mathrm{~mm}$ occurred once every 10 years period in Pomerania region.

Table 1. Areas within particular slope intervals in the Jeleni Brook catchment

\begin{tabular}{c|c|c}
\hline \multirow{2}{*}{$\begin{array}{c}\text { Slopes } \\
\%\end{array}$} & ha & $\%$ \\
\cline { 2 - 3 } $0-3$ & 800.52 & 24.5 \\
$3-6$ & 811.37 & 24.8 \\
$6-9$ & 644.95 & 19.7 \\
$9-12$ & 420.79 & 12.9 \\
$12-15$ & 260.08 & 7.9 \\
$15-18$ & 151.46 & 4.6 \\
$18-24$ & 128.11 & 3.9 \\
$>24$ & 54.72 & 1.7 \\
Mean & & 7.5 \\
\hline
\end{tabular}

Another important factor for water erosion in the catchment is the technique of crop production. During heavy storms the fields with row cultivation as that of potatoes or maize as well as fields with belated growth of crops caused by late spring sowing are particularly susceptible to outwashing. 
According to historical data the areas were deforested and used for agricultural purposes already in the late Middle Ages. Hence, the duration of erosive processes can be estimated at c. 600 years (ŚLASKI, 1951). In the field one may observe distinct traces of water erosion and agricultural erosion made by ploughing. As an effect of these two processes, soil cover is markedly heterogeneous with new forms of relief, the so-called agricultural terraces. These forms are ploughed and occur most often at the borders between arable lands and grasslands or between croplands and forests. There are also another forms of an escarp formed by cutting the slope e.g. at the real estate borders. Digging only one-sided furrows resulted in the movement of earth and denudation of the area situated above in a form of an escarp.

\section{FORMS AND EXTENT OF EROSION}

Water erosion recorded in the catchment basin of the Jeleni Brook is termed the surface runoff which produces small rills (ditches) on a slope and deposition of eroded material in the so-called deluvial fans. At the break of March and April waters from melting snow carve rills in soils made of sandy loams in humus horizons on slopes under winter crops (wheat, rye).

Sometimes soil erosion caused by intensive storm precipitation starts in the middle of April and ends in June. Agrotechnical status of fields exerts the crucial influence on erosion during this period. Intensive precipitation may occur early when fields are just after cultivation and sowing of spring crops. Storm precipitations that occur later are dangerous for potatoes, maize or later sown spring cereals. Young plants can not protect the soil because of incomplete soil coverage.

Waters from melting snow produce rills almost every year. In frozen sandy loam soils rills are of the following sizes: width from 11.5 to $13.6 \mathrm{~cm}$, depth - from 6.4 to $7.1 \mathrm{~cm}$ and length - from 39 to $112 \mathrm{~m}$. (Fig. 3).

The latter dimension depends on the length of a slope. Erosion was found on slopes over 5\% of inclination. Soil material deposited in deluvial fans at the foot of slopes is sorted and outwashed by precipitation and is usually enriched in organic matter. Depending on the size of the catchment (from 1.1 to $14.7 \mathrm{ha}$ ) collected material weighed from 2 to $17.8 \mathrm{t}$. The amount of surface runoff varies thus from 0.5 to $2.02 \mathrm{t} \cdot \mathrm{ha}^{-1}$.

The thickness of sediments in deluvial fans is uneven, usually varies between 4 and $10 \mathrm{~cm}$ but sometimes might reach $14-20 \mathrm{~cm}$. Depending on the shape of lower parts of a slope, deluvial sediments may be wholly or only partly retained. Foot of the slope open for precipitation waters retains only coarse-grained dust-sandy material $(1-0.05 \mathrm{~mm})$ while finer soil particles $(<0.02 \mathrm{~mm})$ leave the field and reach nearby ditch or stream. Such distribution of material in the deluvial fan indicates far advanced sorting of outwashed soil material. 


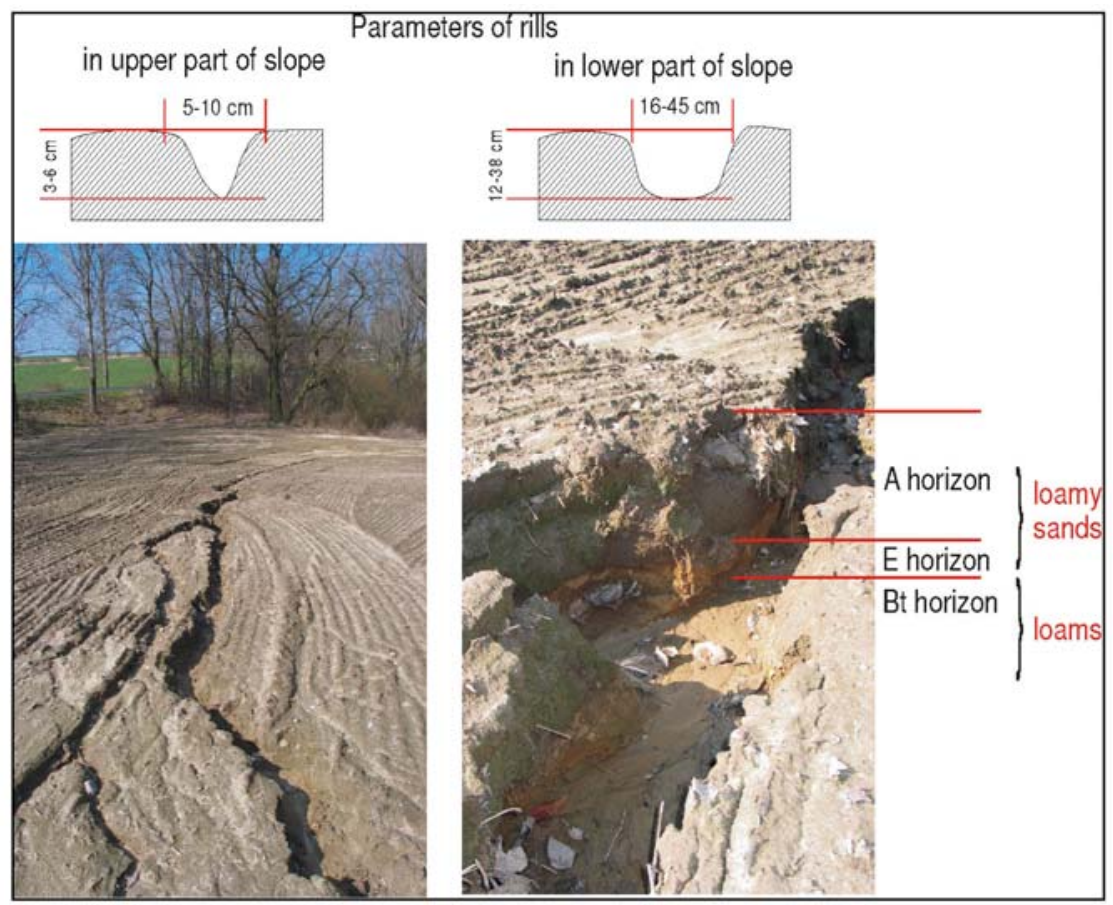

Fig. 3. Winter and early spring erosion resulting from melting snow (photo M. Podlasiński)

Sandy material is relatively poor in humus ( $0.6 \%$ on average) while silty-clay material contains it up to $4 \%$. Differentiated grain size distribution is followed by the abundance of available forms of $\mathrm{P}, \mathrm{K}$ and $\mathrm{Mg}$ (TOMASZEWICZ, 2001). Sediments were found to contain relatively much phosphorus from 21.25 to $48.85 \mathrm{mg}$ $\cdot 100 \mathrm{~g}^{-1}$ of soil. The element at neutral soil $\mathrm{pH}$ is typically transported in combination with soil particles and to a smaller extent in dissolved forms. This regularity was not valid for magnesium; irrespective of the grain size the content of this element in sediments was low ranging from 0.2 to $0.4 \mathrm{mg} \cdot 100 \mathrm{~g}^{-1}$ of soil. It means that erosive transport (surface runoff) removes magnesium out of the catchment in dissolved rather than in particulate form. Erosive transport of potassium differed depending on grain size distribution, coarse fractions were poorer in potassium (7.3-9.2 $\mathrm{mg} \cdot 100 \mathrm{~g}^{-1}$ of soil) than silty-clay parts which contained potassium in concentrations up to $24.9 \mathrm{mg} 100 \mathrm{~g}^{-1}$ of soil. $\mathrm{Na}, \mathrm{Ca}, \mathrm{P}$ and microelements were also washed out to surface waters. $24-35 \mathrm{mg} \mathrm{Cu} \mathrm{kg}^{-1}$ of soil, $114-136 \mathrm{mg} \mathrm{Zn} \mathrm{kg}$ of soil, 538-554 mg Mn kg-1 of soil, 5186-5240 mg Fe kg-1 of soil might runoff with the finest soil particles. The surface area of the subbasin of deluvial fan was 8.8 ha and the runoff was $2.0 \mathrm{t}$ per hectare.

Erosion caused by intensive storm precipitation occurs less often but makes much higher soil losses and its impact on aquatic ecosystems is also greater. Such a 
case of erosion was recorded on May $14^{\text {th }}$ 1997. An exceptional rainstorm $(28 \mathrm{~mm}$ within 17 minutes) with the hail (diameter of $12-17 \mathrm{~mm}$ ) was noted on that day.

According to CHOMICZ'S (1951) classification the storm has B1 symbol, and rainfall erodibility factor was $47.3 \mathrm{MJ} \cdot \mathrm{ha}^{-1} \cdot \mathrm{cm} \cdot \mathrm{ha}^{-1}$ (BANASIK, GÓRSKI, 1990; WISCHMEIER, SMITH, 1978). For comparison it can be added that the sum of all precipitations in the years 1998 and 1999 did not reach this value. The occurrence of such erosion was mainly observed in row crops (potatoes, Photo 1) and in spring wheat where plants were small yet.

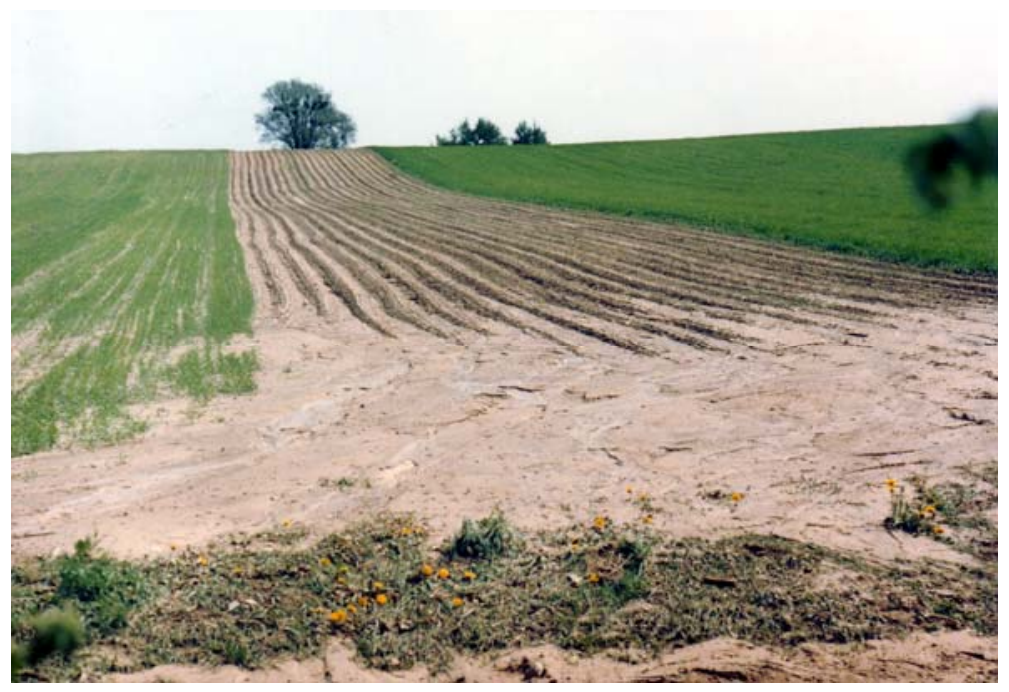

Photo 1. An example of large soil runoff in potato crop after storm precipitation in 1997 in Brwice

Soil wash-dawn from potato crop was so large that it covered the asphalt road along crops and caused problems in car communication. The amount of these deposits was not measured since they were removed.

The amount of these deposits can be evaluated by comparison with erosion measure on another field on which spring wheat was cultivated. This field is enclosed from 4 sides by balks and makes a closed subbasin of an area of 0.66 ha (Fig. 4). Soil texture was sandy clay loam, and the average slope of subbasin was $14.5 \%$.

Erosion in wheat had a rare character of layered runoff (lacking flutes) and performed calculations showed that uniformly washed soil layer had a thickness of $4.5 \mathrm{~mm}$ on the whole catchment ( $0.66 \mathrm{ha}$ ) of the trap. The mass of washed material reached $32.6 \mathrm{t}$ which was equivalent to $49.4 \mathrm{t}$ per hectare. 


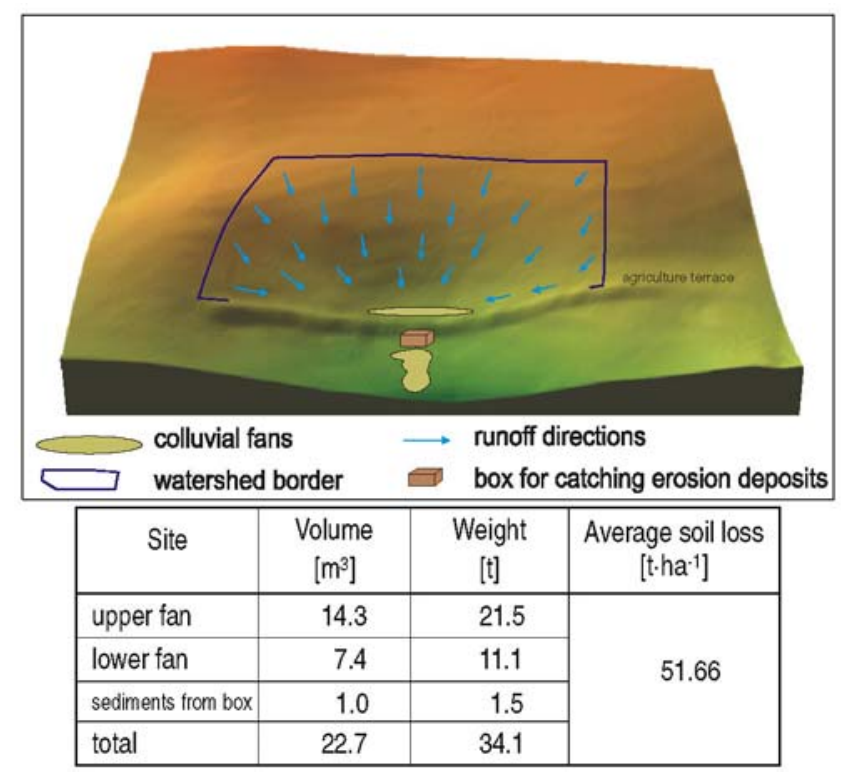

Fig. 4. Soil erosion in spring wheat field caused by storm in 1997

A huge mass of water flowing down the slope breaks small obstacles on its course like ditches, roads, shallow depressions at the foot of the hills and thus it gets easier to running waters. The water transports mentioned earlier mineral and organic colloidal particles and various combined or dissolved elements. The input of soil particles and chemical elements to open waters is many times greater. Obtained results, in spite of their fragmentary character, confirmed the thesis that water erosion was an important factor in the supply of chemical elements to surface waters.

Agricultural erosion caused by ploughing occurs simultaneously with the runoff of precipitation and soil washing. It is hard to separate the two processes. Long time since deforestation (c. 600 years) in the village Brwice left numerous escarps (agricultural terraces) shown in the map (Fig. 5). These transformations exert strong impact on relief. Due to the formation of a thick (maximum $2 \mathrm{~m}$ ) and extent ( $150 \mathrm{~m}$ long at the grassland border and up to $30 \mathrm{~m}$ wide) layer of deluvial deposits at the foot of the slope, the inclination flattened and the field laid on the grassland. This markedly improved soil tillage and was supposedly an intended human activity. It also decreased soil erosion on slope.

Agricultural terraces evidence the transformation of soils subjected to water and agricultural erosion. Studies performed in a $1 \mathrm{~m}$ wide selected section of such terrace allowed for estimating the amount of outwashed soil humic material at $51 \mathrm{t}$ (Fig. 6). Estimates for the whole terrace gave the volume of $1480 \mathrm{~m}^{3}$ or the mass of $2200 \mathrm{t}$. 


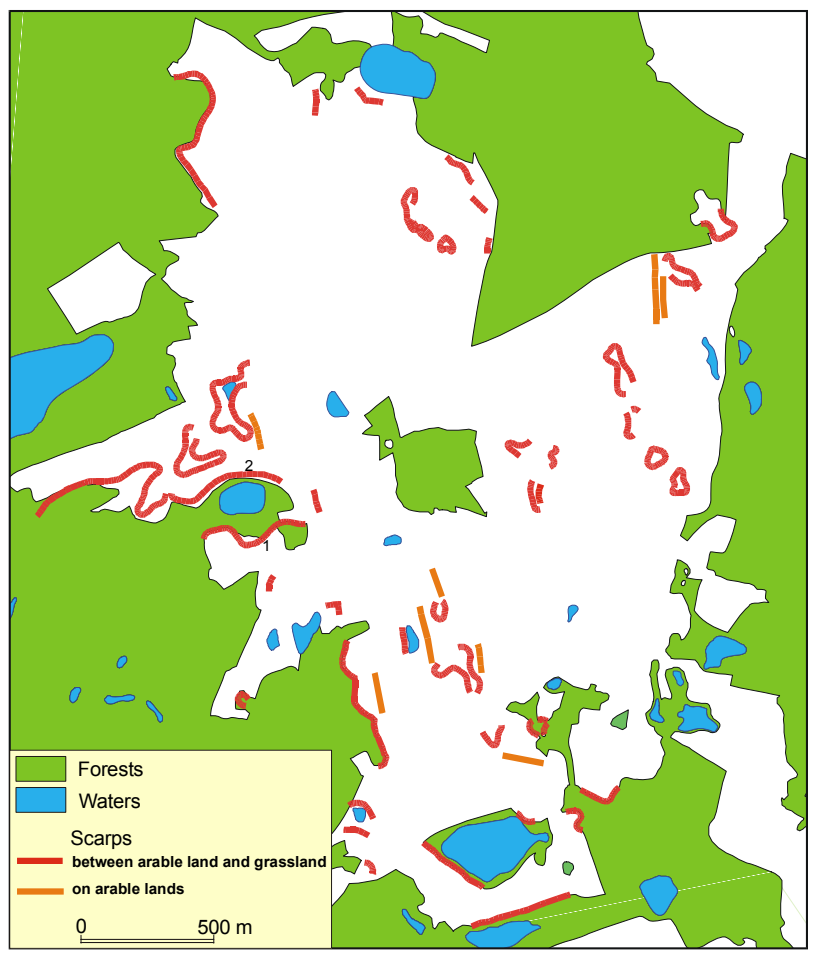

Fig 5. Distribution of agricultural terraces in the village Brwice

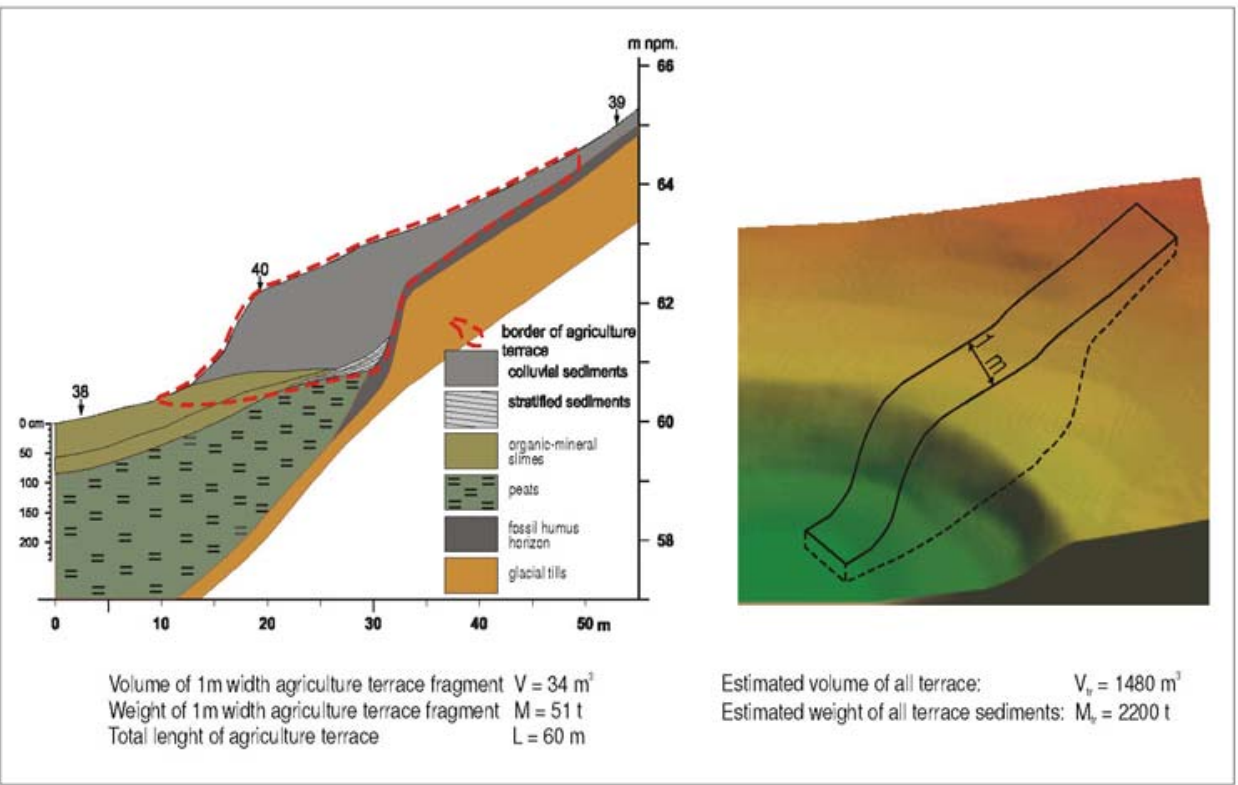

Fig. 6. Structure of agriculture terrace 
This mass of soil material originates from the field lying on slope with present area of 4.02 ha. This field in more steep part is bordered by country road from one side and by forest from the other. At the foot the slope is closed by grasslands on peatbog. Nowadays, strongly eroded soils cover 0.89 ha of this field. Soil losses were thus $550 \mathrm{t}$ per hectare of the field area. These soils during 100 years lost $92 \mathrm{t}$ of material rich in organic mater form every hectare (estimating about 600 years of their agriculture use). Such high erosion rate resulted from water and ploughing erosion.

Field studies in Brwice revealed about $11.5 \mathrm{~km}$ of escarps at the borderline between fields and grasslands which made the density of $2.45 \mathrm{~km} \cdot \mathrm{km}^{-2}$.

\section{CONCLUSIONS}

1. According to Polish classification of erosion events high erosion in the Jeleni Brook catchment can be classified as washing down and rill erosion but does not involve gully erosion.

2. Arable soils of the Jeleni Brook basin are strongly transformed by water erosion and currently require counter erosion measures to maintain their fertility at good agrotechnical level.

3. In counter erosion policy we need to consider either agrotechnical activities that would aim at making protective plant cover or to provide changes in crop structure eg. to intend part of the most eroded arable lands for permanent grasslands and arable (extensive) farming supported by agrotechnical services.

4. In the case of significant transformation in areas of complex relief, the soils should be classified as "marginal soils" and, according to legal regulations, excluded from agricultural use and qualified to afforestation.

\section{BIBLIGRAPHY}

1. BANASIK K., GÓRSKI D., 1990. Wyznaczanie erozyjności deszczy do uniwersalnego równania strat gleby. (Estimating erodibility of rainfalls for the universal equation of soil losses). Zesz. Nauk AR Wroc. Melior. 34 nr 189: 36-44.

2. ChudeckA J., 2001. Zawartość $\mathrm{Cu}, \mathrm{Zn}, \mathrm{Pb}, \mathrm{Mn}$ w erodowanych glebach strefy czołowomorenowej Pomorza Zachodniego. (The content of $\mathrm{Cu}, \mathrm{Zn}, \mathrm{Pb}, \mathrm{Mn}$ in eroded soils of the frontal morainic zone of West Pomerania). Folia Univ. Agricult. Stetin. 217 Agricult. (87): 73-76

3. Chомicz K., 1951. Ulewy i deszcze nawalne w Polsce. (Rainstorms and torrential rains in Poland). Wiad. Służby Hydrol. Meteor. 2 z. 3: 5-58.

4. JózefaciuK A., JózefaciuK Cz., 1999. Ochrona gruntów przed erozją. Poradnik dla władz administracyjnych i samorządowych oraz służb doradczych i użytkowników gruntów. (Protection of grounds against erosion. A guide for local authorities, advisory services and land users). Puławy, IUNG: 110. 
5. Koćmit A., Chudecka J., Podlasiński M., Raczkowski B., Roy M., Tomaszewicz T., 2001. Przestrzenna zmienność pokrywy glebowej na erodowanym zboczu $\mathrm{w}$ obszarze morenowym Pomorza Zachodniego. (Spatial variability of soil cover on eroded slope in morain area of West Pomerania) Folia Univ. Agricult. Stetin. 217 Agricult. (87): 97-101.

6. Koćmit A., RACZKowski B., PodLAsińsKi M., 2001. Typologiczna przynależność erodowanych gleb wytworzonych z glin morenowych wybranego obiektu na Pomorzu Zachodnim. (Typology of eroded soils made of boulder loams in selected object of West Pomerania). Folia Univ. Agricult. Stetin. 217 Agricult. (87): 103-107.

7. KoźmiŃski Cz., TrZeciak S., 1978. Opady o natężeniu powyżej $20 \mathrm{~mm}$ na dobę na terenie Pojezierza Pomorskiego w latach 1955-1975. (Rainfalls of an intensity exceeding $20 \mathrm{~mm}$ per day in Pomeranian Lakeland in the years 1955-1975) Zesz. Nauk. AR Szczec. Rol. (68) Ser. Przyr. 18: 99-113.

8. PodlAsińSKi M., 2001a. Erozja antropogeniczna oraz jej przejawy w obrębie wsi Brwice. (Anthropogenic erosion and its expression in village Brwice). Folia Univ. Agricult. Stetin. 217 Agricult. (87): 189-193.

9. PODLASIŃSKi M., 2001b. Erozja wodna i jej wpływ na gleby w małej zlewni leśno-rolniczej w dorzeczu Rurzycy w strefie czołowomorenowej fazy pomorskiej zlodowacenia Vistulian. (Water erosion and its effect on soils in a small field-forest catchment in the Rurzyca basin in frontal morainic zone of the Pomeranian phase of Vistulian glaciation). Szczecin: AR pr. dokt. maszyn.

10. RoY M., 2001. Zasoby fosforu i jego podatność na migrację w erodowanych glebach obszaru moreny czołowej na Pomorzu Zachodnim. (Resources of phosphorus and its susceptibility to migration in eroded soils of the frontal morain in West Pomerania). Folia Univ. Agricult. Stetin. 217 Agricult. (87): 205-208.

11. ŚLASKi K., 1951. Zasięg lasów Pomorza w dobie historycznej. Mapa Zasięg lasów w ostatnim tysiącleciu. (The range of Pomeranian forests in the past. Map of forest range in the last millenium). Mater. Prz. Zach. 14: 207-223.

12. TOMASZEWICZ T., 2001. Zmiany żyzności gleb spowodowane erozją wodną na obiekcie Brwice. (Changes of soil fertility caused by water erosion in Brwice). Folia Univ. Agricult. Stetin. 217 Agricult. (87): 227-231.

13. WischmeIER W.H., SMith D.D., 1978. Predicting rainfall erosion losses - A guide to conservation planning. USDA Agricult. Handbook (537): 57.

\section{STRESZCZENIE}

\section{Erozja wodna w zlewni Potoku Jeleniego}

Słowa kluczowe: czynniki erozji, erozja uprawowa, erozja wodna, osady erozyjne, straty gleby

W latach 1995-1999 rejestrowano osady erozyjne i żłobiny na gruntach ornych w terenie czołowomornowym w zlewni rolno-leśnej Potoku Jeleniego. Obszar zlewni wyróżnia się spośród innych intensywną rzeźbą młodoglacjalną (zbocza o znacznych spadkach) i częstszym występowaniem opadów intensywnych - burzowych, przez to jest silniej zagrożony erozją wodną. Do czynników erozyjnych kształtujących erozję wodną należy zaliczyć także: agrotechnikę (niekorzystne uprawy rzędowe roślin), pojawienie się wód roztopowych wczesnowiosennych. 
Erozja wodna przybiera formę spłukiwania powierzchniowego o nasileniu od słabego do umiarkowanego lub średniego według 5-stopniowej skali przyjętej w Polsce. Erozja powodowana wodami topniejącego śniegu wykształca żłobiny o wymiarach (według wartości średnich): szerokość 11,5-13,6 cm, głębokość 6,4$-7,1 \mathrm{~cm}$ długość 39-112 m. Średnia wielkość zmywu glebowego wyniosła 0,5$-2,02 \mathrm{t} \cdot \mathrm{ha}^{-1}$.

Opady burzowe pojawiają się rzadziej, lecz przyczyniają się do silniejszego rozwoju procesów erozji, przybiera ona bardziej wyraziste formy żłobinowe lub nawet formę zmycia warstwowego, przy którym jest odtransportowana z pola cała warstwa gleby (np. 4,5 mm, na powierzchni $0,66 \mathrm{ha}$ ). Zarejestrowany zmyw gleby wyniósł w takim przypadku 51,6 thha ${ }^{-1}$.

Zmyty materiał glebowy podlega daleko idącej segregacji w obrębie stożka erozyjnego i wykazuje odpowiednio zmienione właściwości chemiczne. Pierwiastki chemiczne podlegają przy tym transportowi związanemu z cząsteczkami glebowymi lub w formie rozpuszczonej i wtedy mogą odpływać poza granice erodowanego pola, do sieci hydrograficznej.

Pierwotną przyczyną uruchomienia się procesów erozji wodnej było wylesienie tych obszarów dokonane w średniowieczu i objęcie ich użytkowaniem rolniczym. Według danych historycznych można szacować okres po wylesieniu (okres użytkowania rolniczego) na około 600 lat. W tym czasie na procesy erozji wodnej nałożyły się procesy erozji uprawowej związane z uprawą gleb, pracą narzędzi rolniczych, a szczególnie w ostatnich stuleciach z pracą pługa. Sumowanie się efektów zmycia i naorywania gleby w dolnych częściach zboczy, wytworzyło nowe formy rzeźby terenu, tzw. terasy rolne. Terasy rolne przybierają formę skarp o wysokości do $2 \mathrm{~m}$ i różnej długości (np. $150 \mathrm{~m}$ ) o przebiegu zgodnym z granicą użytkowania, na styku las - pole, pole- użytek zielony, lub po granicy własności. W tym ostatnim przypadku skarpa powstaje przez podcięcie zbocza i odprowadzanie materiału glebowego w dół. Stwierdzono łącznie 11,5 km skarp, daje to wskaźnik zagęszczenia $2,45 \mathrm{~km} \cdot \mathrm{km}^{-2}$.

Gleby użytkowane rolniczo $\mathrm{w}$ granicach zlewni wymagają działań ochronnych, głównie opartych o agrotechnikę, a niekiedy także zmiany sposobu użytkowania. Niektóre obszary powinny być przeznaczone pod zalesienie.

Received 19.10.2005

Reviewers:

Prof. Edward Pierzgalski

Prof. Stanistaw Patys 